\title{
Tietokonelukutaito
}

\section{SAATKO SELKOA TIETOKONEMYYJÄSTÄ?}

',Ja sitäkään en ymmärrä, miksi aina tyhmin mies pannaan hankkimaan buljun kaikki tietokoneet', täräytti fiksu nainen luovan tekstinkäsittelyn kurssilla.

Enpä osannut vastata. Usein hankinnoista tosiaan päättänee mies, vaan mitämaks hän ei ole ihan niin tyhmä, mitä koneista ja ohjelmista voisi päätellä. Hänellä on vain kehno itsetunto. Ja tietokonekaupoissa kun tarvittaisiin rohkeutta.

Atk-alalla myyjä on röyhkeä. Muutama poikkeus vahvistaa sääntöä. Kilpailu on koventunut, vaan tavat eivät ole parantuneet.

Myyjän suunsoitto kielii paljon - ja sanoo vähän. Hän puhuu kellotaajuuksista ja kapasiteeteista, huolloista ja optioista. Ja "toiminnoista" - se on hänen mielisanansa. Väliin hän ripauttaa jonkin fraasin, että ostaja kuvittelee olevansa mukana:

' Hyvästähän täytyy maksaa.' Ostaja nyökkää. '’Ja kyllähän kotimainen on se, johon voi luottaa." Tai: ' 'Tunnettuun merkkiin kannattaa sijoittaa."

Kauppa käy ja niin oppilaitoksissakin näkee mitä hienoimpia koneita. Fraasit on otettu täy- destä, mikä on tiennyt ylihintaista laskua ja mitä kirjavimpia koneita, paljon niin sanotusti kotimaista - sekä viritelmiä, jotka on suunniteltu "erikoisesti opetustarkoituksiin". Ja kalliita ohjelmia!

Hölmöintä opistojen tietokonehankinnoissa on, että monesti ei tarkkaan tiedetä, miksi ylisummaan hankitaan tietokonetta. Ostetaan koska muuallekin ostetaan. Luullaan, että ne pitää olla. Kuvitellaan kaikkea.

Tuore yhdysvaltalainen tutkimus kertoo, että toimistojen työteho on parantunut vuodesta 1950 siinä viitisen prosenttia. Ei siis juuri mitään. Tietokoneet kyllä rouskuttavat kovasti, mutta suoltavat paperia, joista yli 80 prosenttia ei pääse edes Ö-mappiin.

Opetusministeriössä aletaan meilläkin myöntää, että kallista tosiaan oli menneen vuosikymmenen atk-huuma ja niukasti se antoi. Ei, älkää tuomitko vanhoilliseksi. En syytä laitetta enkä sen ohjelmia. Kirjailijoista minä olin Suomessa ensimmäinen joka hankin tietokoneen ja graafikkona käytän sitä myös. 
Tietokonealalla on rehellisiäkin neuvonantajia. Heidän tunnuksensa on KISS, 'Keep It Simple And Stupid'. Hyvä ratkaisu on yksinkertainen kone ja halvat, toimivat ohjelmat.

Huokea hinta on yksi PC-alan iloisimpia innovaatioita. Paras kone on tehty niin, että hintakin on edullinen.

Utele muiden kokemuksia ja kysy vaikeuksista. Hämmästyt. Jo sellainen perusasia kuin kirjoittimen asennus voi aiheuttaa isoja vaikeuksia. Ja tuosta palvelusta kehdataan vielä laskuttaa eikä vallan vähääkään.

Vaan entä jos opisto saa kalliista koneesta hyvän alennuksen? Ei kai kukaan noin älyvapaita kysy. Raha ei korreloi teknisen laadun kanssa ja kallis pysyy houkuttelevan alennuksen jälkeenkin kalliina - ja lisälaitteet ja huollot eivät taatusti ole ilmaisia.

Onhan vielä kyse yhteiskunnan varoista. Niin hölmö ei sovi olla, että hassaa rahat koneeseen, jota pontevammin tuputetaan ja jossa on hienouksia.

Opettaa voi ilman tietokonettakin. Kone ei ole must. Mutta jos opistoon on hankittu laitteet, niin haaste on tarjota opetusta kohtuuhintaan.

Opistot ovatkin tervehdyttäneet atk-alaa. Kun kaupallinen kouluttaja voi yhä pyytää kurssista parikin tonnia päivältä, niin moni opisto tarjoaa moiseen hintaan paremman koko viikon kurssin ja hintaan sisältyy täyshoito.

Koska opistoissa uskalletaan miettiä opetusta raikkaasti uusiksi, parhaimmillaan kurssien anti on vertaansa vailla. Se ei ole pysähtynyt värikalvojen ja sarkainasetusten tasolle. Haapaveden opistolta pyysivät jokin vuosi sitten yhdistettyä tietokone- ja kirjoituskurssia. Idea sytytti. Uusi kirjoituskeino innosti oppilaita ja myös minua.

Väline lisäsi ilmaisullista rohkeutta sekä tarmoa. Kirjoittamisen sivussa tulivat kirjoitusohjelman piilovoimatkin tutuiksi.

Sittemmin olen pitänyt vastaavia kursseja tiedottajille, papeille, opettajille, toimittajille. Olen kärsinyt ihmeellisistä laitevalinnoista, "tehokkaista" levyasemista, oudoista ohjelmista - ja noista opetusverkoista: ne ovat opettaneet minua huoltomieheksi.
Olen kummastellut aikuisopetuksen määrärahoja. Monessa opistossa on tuhlattu tuhansia ja taas tuhansia markkoja ohjelmiin, joiden tarvetta en ymmärrä.

Toki olen opettanut myös kaupallisia ohjelmia, mutta tehnyt sen useimmiten halpojen ja selkeiden vaihto-ohjelmien avulla (shareware).

Niillä pystyy näyttämään, mitä ohjelmalta sopii vaatia ja kuta kaikkea sieltä löytyy piiloista voimaa. Kukin voi sitten lukea WP:n tai Microsoft Wordin käsikirjasta, miten noissa ohjelmissa ikkunoidaan, luonnostellaan, limitellään eri tiedostoja ja käytetään laitetta muuhunkin kuin liikekirjeen naputtamiseen.

Vaihto-ohjelma maksaa muutaman kymmenen dollaria. Niistä pitävät kaikki paitsi eivät atk-kauppiaat. Usein oppilaat haluavat kopion kokeiltavaksi, jolloin saa ohimennen neuvoa, kuinka raha menee Yhdysvaltoihin ja mitä on yhdentyvä talous.

Tietokoneitten hankinnassa ja niiden käytössä on kysyttävä apua viisailta naisilta. Mallin saa vaikka nypläys- tai keittotaitokurssilta: vähin ostoin voi antaa kelpo opetusta, kunhan tietää mitä tahtoo ja tahtoo sen, minkä tietää.

Asialla on henkilö, joka tietää kuinka nyplätään, miksi kokataan ja millä lailla noista taiteista saa enemmän irti, jahka käyttää hoksottimia ja opettelee oikeat asiat. Atk-ala ei ole sen kummoisempi. Hankitaan siis yksinkertainen kone ja siihen huokeat ohjelmat - mikäli ne tuntuvat tarpeellisilta.

\section{ARTO KYTÖHONKA}

